\title{
Thermal Performance of Clay Bricks, Lime Bricks, and Ventilation Blocks as Building Walls
}

\author{
Iwan Wibisono*
}

\author{
Department of Architecture, Faculty of Engineering, Universitas Brawijaya, Malang, Indonesia \\ *Corresponding author. Email: iwanwibisono@ub.ac.id
}

\begin{abstract}
Indonesia is one of the countries affected by climate change. One of the most significant effects that happen in the environment is global warming, which causes the air temperature to rise. Climatic conditions will directly affect the human body since the air temperature influences the human body. Indonesia is also one of the countries facing an energy crisis. Efforts are certainly needed to keep the thermal comfort inside the building within the tolerable level, while on the other hand minimizing the use of energy for air conditioning. One way is by optimizing the building envelope materials to reduce the room temperature. This method is based on the fact that conductivity (other than convection and radiation) of building materials greatly influences heat transfer, especially through the building walls. This study aims to discover the thermal performance of clay bricks, lime bricks, and ventilation blocks as wall construction. The study used qualitative and quantitative methods, aided with field measurements. The conclusion is made based on the comparison result of the best temperature reduction between clay bricks, lime bricks, and ventilation blocks. Keywords: Thermal comfort, temperature reduction, clay bricks, lime bricks, ventilation blocks
\end{abstract}

\section{INTRODUCTION}

Indonesia is one of the countries affected by climate change. One of the most significant effects that happen in the environment is global warming, which causes the air temperature to rise. Climatic conditions will directly affect the human body since the air temperature influences the human body. Indonesia is also one of the countries facing an energy crisis. Efforts are certainly needed to keep the thermal comfort inside the building within the tolerable level, while on the other hand minimizing the use of energy for air conditioning. One way is by optimizing the building envelope materials to reduce the room temperature. This method is based on the fact that conductivity (other than convection and radiation) of building materials greatly influences heat transfer, especially through the building walls. By analyzing material characteristics used on a building, it will lead to the result of which material can produce the most significant temperature reduction.

\section{RESEARCH METHODS}

This study uses qualitative and quantitative methods. Qualitative method is used by elaborating the description of the object, from literature studies, visual observation, temperature data information, and site and building data. The quantitative method is by direct measurements in the research location.
Field measurements are carried out at several rooms with criteria as follows: the same size of the room, the same type of roof and ceiling material, the same orientation, the difference only in the wall material. This research was conducted at three types of buildings in different locations: 1) the MUTOS Office in Seloliman Village, Trawas District, Mojokerto Regency [1]; 2) three houses in Montong and Grabagan Villages, and the North Coast Road of Tuban Regency [2]; and 3) five boarding houses in Keputih District, Surabaya City [3].

The temperature is measured both on the exterior and interior. The temperature measurement used the HOBO data logger for \pm 7 days during work hour $(08.00$ a.m. 04.00 p.m.) with the closed window condition. The instrument is placed at the center of the room with a height of $1.1 \mathrm{~m}$, while the placement at the outdoor is at the height of $2 \mathrm{~m}$ from the floor surface [4].

After doing visual analysis stage and field temperature measurement, the analysis was carried out to compare the result of field temperature measurement from three wall materials (clay bricks, lime bricks, and ventilation blocks) that will be done in digital simulation. After the analysis process is done, the results will be obtained at which material is the best in temperature reduction. 


\section{RESULT AND DISCUSSION}

\subsection{Clay Bricks}

\subsubsection{Outdoor Air Temperature}

MUTOS Office had walls made of red clay bricks. There are trees with a broad canopy located on the east and west of the building. On the east side of the building, there is a tree of a $\pm 10 \mathrm{~m}$ height located $\pm 1 \mathrm{~m}$ from the building, a coconut tree with a height of $\pm 6 \mathrm{~m}$ located $\pm 7 \mathrm{~m}$ from the building, and a tree with a height of $\pm 10 \mathrm{~m}$ located $\pm 9 \mathrm{~m}$ from the building. On the west, there is a tree with a height of $\pm 10 \mathrm{~m}$ located $\pm 1 \mathrm{~m}$ from the building.
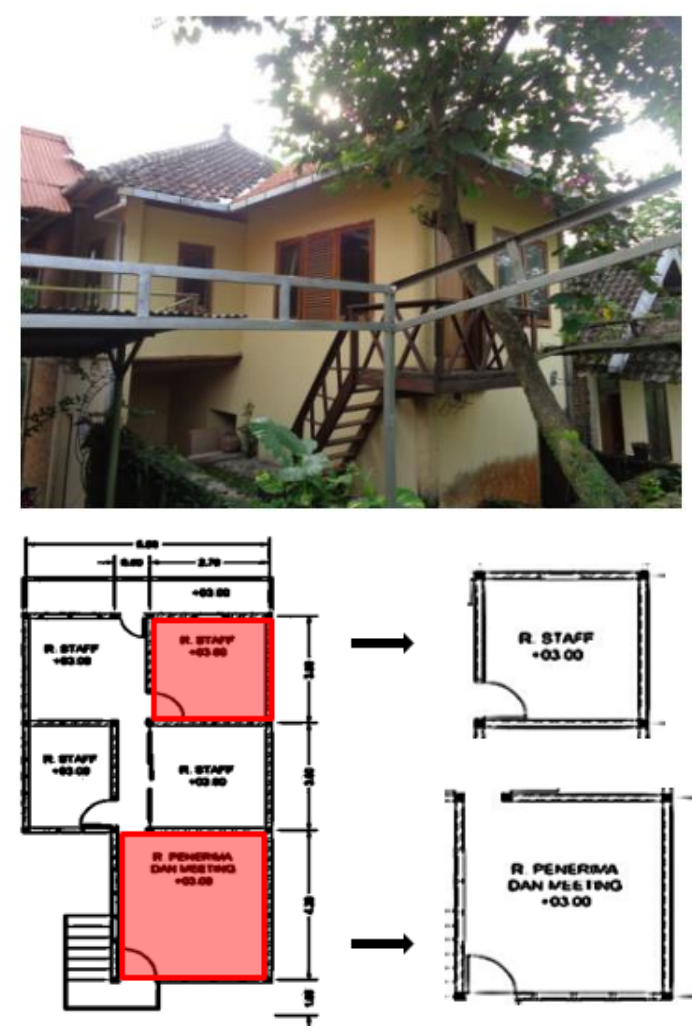

Figure 1 Floor plan of the MUTOS Office

According to the observation, outdoor air temperature reached the highest point at 12.00 a.m. However, if evaluated from the average air temperature, the outdoor air temperature reached the highest point at 11.00 a.m., which is $30.08^{\circ} \mathrm{C}$.

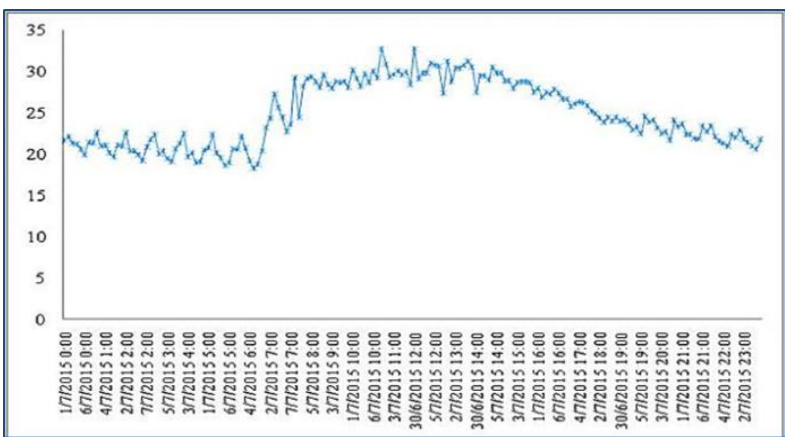

Figure 2 Outdoor air temperature

\subsubsection{Indoor Air Temperature}

Observation points inside the building are located in the workspace and lobby. The highest indoor temperature occurred at 01.00 p.m. at $30.12^{\circ} \mathrm{C}$, while the lowest temperature is at 06.00 a.m. at $18.56^{\circ} \mathrm{C}$. The highest temperature reduction occurs at $02.00 \mathrm{p.m}$. at $28.45^{\circ} \mathrm{C}$. Based on the standards [5], the measured air temperatures are still in a comfortable range, except at 01.00 p.m. 05.00 p.m. Temperature reduction occurs from 06.00 a.m. until 03.00 p.m. The highest temperature reduction of $8.30^{\circ} \mathrm{C}$ occurs at 08.00 a.m. The most significant average temperature reduction in the workspace is $5.78^{\circ} \mathrm{C}$ and $5.00^{\circ} \mathrm{C}$ in the lobby.

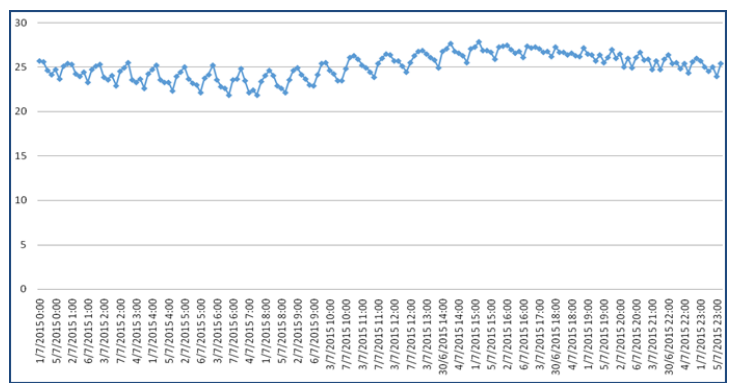

Figure 3 Indoor air temperature of workspace with clay bricks wall

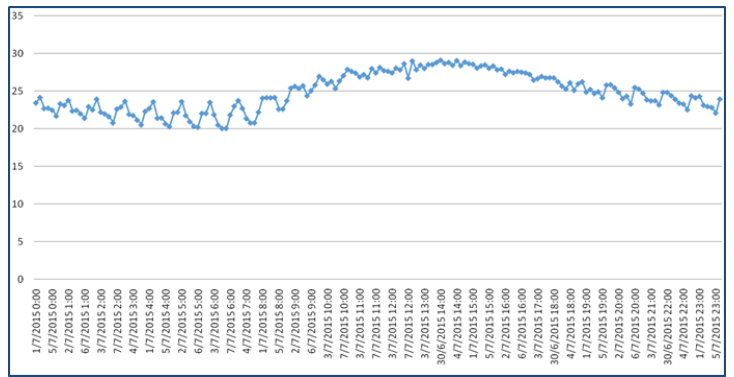

Figure 4 Indoor air temperature of the lobby with clay bricks wall 


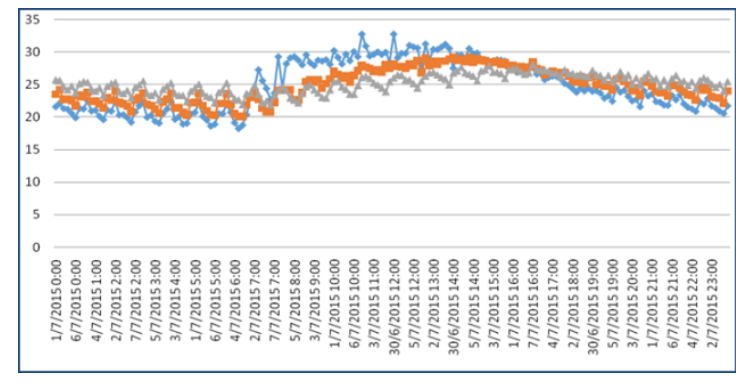

Figure 5 Air temperature reduction with clay bricks wall

In the workspace and lobby, the highest air temperature occurs at 02.00 p.m. at $29.12^{\circ} \mathrm{C}$, while the lowest occurs at 06.00 a.m. at $20.05^{\circ} \mathrm{C}$. The highest temperature reduction occurs at 02.00 p.m. at $28.45^{\circ} \mathrm{C}$. Based on the standards [5], the measured air temperatures are still in a comfortable range, except at 11.00 a.m.-05.00 p.m. Temperature reduction occurs from 07.00 a.m. until 03.00 p.m. The highest temperature reduction occurs at 08.00 a.m., $6.68^{\circ} \mathrm{C}$ in the lobby, and $6.67^{\circ} \mathrm{C}$ in the workspace. The highest average temperature reduction in the workspace is $4.50^{\circ} \mathrm{C}$ and $4.71^{\circ} \mathrm{C}$ in the lobby.

\subsubsection{Temperature reduction}

The average temperature reduction in the building occurs at 07.00 a.m. -02.00 p.m. with $2.84^{\circ} \mathrm{C}$ in the lobby, and $3.08^{\circ} \mathrm{C}$ in the workspace. The average air temperature reduction from 07.00 a.m. -02.00 p.m. is up to $2.51^{\circ} \mathrm{C}$ in the lobby and up to $3.84^{\circ} \mathrm{C}$ in the workspace. The outdoor air temperature performance above the comfortable temperature $\left(>28^{\circ} \mathrm{C}\right)$ occurs at 08.00 a.m. -03.00 p.m. The average temperature reduction is up to $1.92^{\circ} \mathrm{C}$ in the lobby and up to $3.42^{\circ} \mathrm{C}$ in the workspace. The reduction from outdoor air temperature is $2.25^{\circ} \mathrm{C}$ in the lobby and $3.88^{\circ} \mathrm{C}$ in the workspace. From the results, the highest average temperature reduction occurs in the workspace.

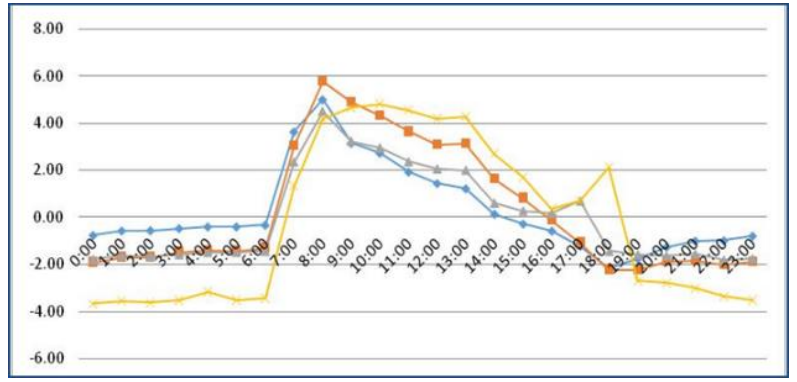

Figure 6 Average air temperature reduction by using clay bricks wall

\subsection{Lime Bricks}

\subsubsection{Outdoor Air Temperature}

The measurement is conducted in several houses in Montong Village, Grabagan Village, and the North Coast Road of Tuban, with walls made of limestone.

According to the field observation results, outdoor air temperature reached the highest point at 12.00 a.m. However, when evaluated from the average air temperature, outdoor air temperature reached the highest point at 11.00 a.m., which is $29.8^{\circ} \mathrm{C}$ in the living room and $30.1^{\circ} \mathrm{C}$ in the bedroom.

\subsubsection{Indoor Air Temperature}

The highest temperature reduction of $2.1^{\circ} \mathrm{C}$ occurs at the houses with an exposed wall at Grabagan Village. The highest temperature reduction at Montong Village is $0.8^{\circ} \mathrm{C}$ and $1.4^{\circ} \mathrm{C}$ at the house in the North Coast Road, which occurs at 09.00 a.m.

Temperature reduction did not occur in G.E sample at 01.00 p.m. -02.00 p.m., the same for M.E sample at 11.00 a.m.-04.00 p.m., and J.E sample at 02.00 p.m.-04.00 p.m. A small temperature reduction of $0.5^{\circ} \mathrm{C}$ occurs in G.E sample at $10.00-12.00$ a.m. and of $0.7^{\circ} \mathrm{C}$ in J.E sample at 10.00 a.m. -01.00 p.m. The average temperature reduction of 24-hours in the G.E sample is $1.2^{\circ} \mathrm{C}$, in the M.E sample is $1.3^{\circ} \mathrm{C}$, and in $\mathrm{J} . \mathrm{E}$ sample is $0.4^{\circ} \mathrm{C}$.

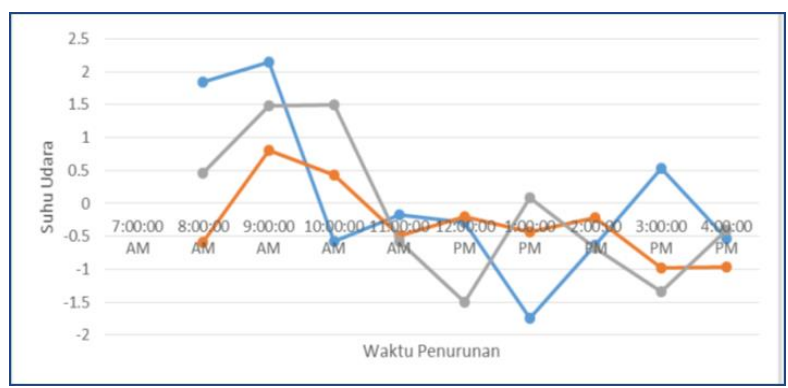

Figure 7 Temperature reduction in the living room by using exposed lime bricks wall

\subsubsection{Temperature Reduction}

The highest temperature reduction in the G.P. sample occurs at 09.00 a.m. with $2^{\circ} \mathrm{C}$, followed by 08.00 a.m. with $1.6^{\circ} \mathrm{C}$, and at 03.00 p.m. with $0.5^{\circ} \mathrm{C}$. There is no temperature reduction at 10.00 a.m. -02.00 p.m. The highest temperature reduction in the M.P sample occurs at 01.00 p.m. with $1.3^{\circ} \mathrm{C}$, followed by 12.00 a.m. with $0.6^{\circ} \mathrm{C}$, and at 04.00 p.m. with $0.5^{\circ} \mathrm{C}$. There is no temperature reduction detected at 08.00 a.m. -11.00 p.m. and 02.00 p.m. The highest temperature reduction in J.P sample occurs at 08.00 a.m. with $1.9^{\circ} \mathrm{C}$, followed by 09.00 a.m. with $1.4^{\circ} \mathrm{C}$, at 10.00 a.m. with $1^{\circ} \mathrm{C}$, and at 11.00 a.m. with $1.7^{\circ} \mathrm{C}$. 
There is no temperature reduction detected at 12.00 a.m.04.00 p.m. The average temperature reduction of 24-hours in the G.P sample is $-0.2^{\circ} \mathrm{C}$, in the M.P sample is $-0.1^{\circ} \mathrm{C}$, and in the J.P sample is $-0.5^{\circ} \mathrm{C}$.

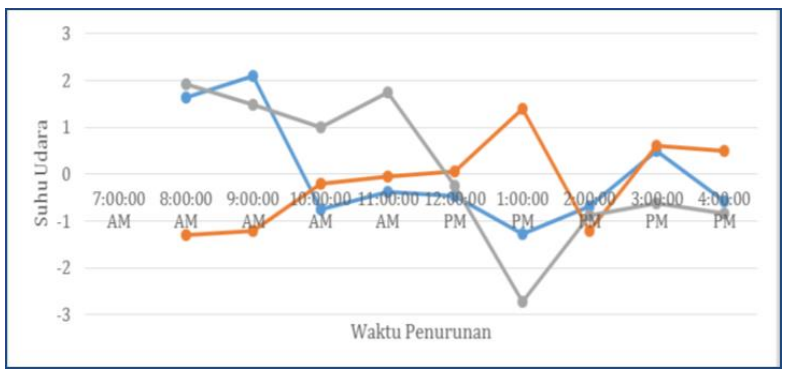

Figure $\mathbf{8}$ Temperature reduction by using plastered lime bricks wall

\subsection{Ventilated Blocks}

The research objects for ventilated blocks wall are boarding houses located in Perumahan Bumi Marina Emas Selatan, Sukolilo District, Surabaya City. There are five boarding houses to be measure, which is Keputih Boarding House Volume 2, 3,4,5,6 by Andy Rahman Architects.

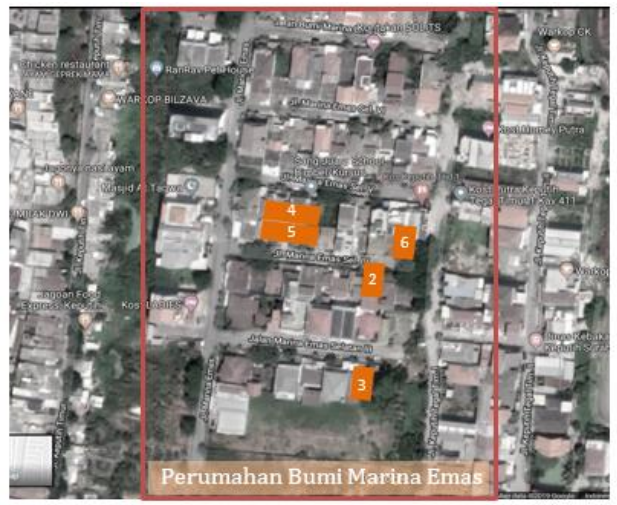

Figure 9 Location of the research objects
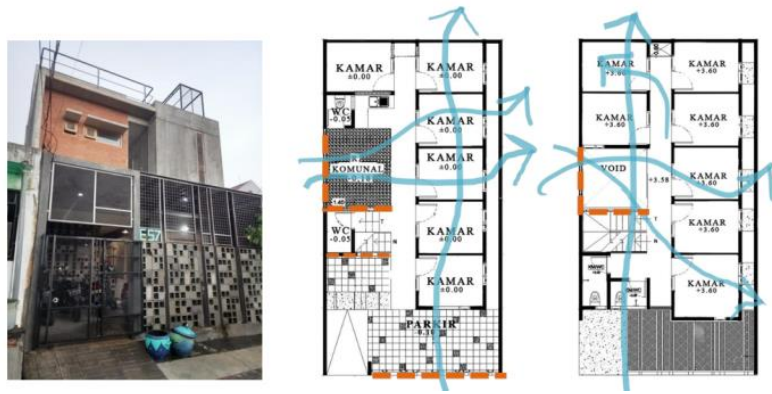

Figure 10 Keputih Boarding House Volume 2 (Object 2)
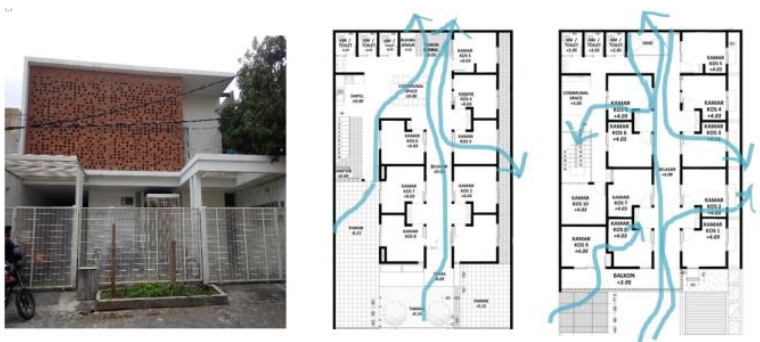

Figure 11 Keputih Boarding House Volume 3 (Object 3)
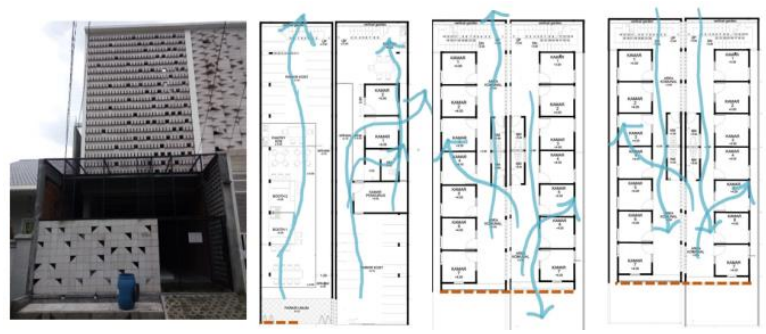

Figure 12 Keputih Boarding House Volume 4 and 5 (Object 4 and 5)
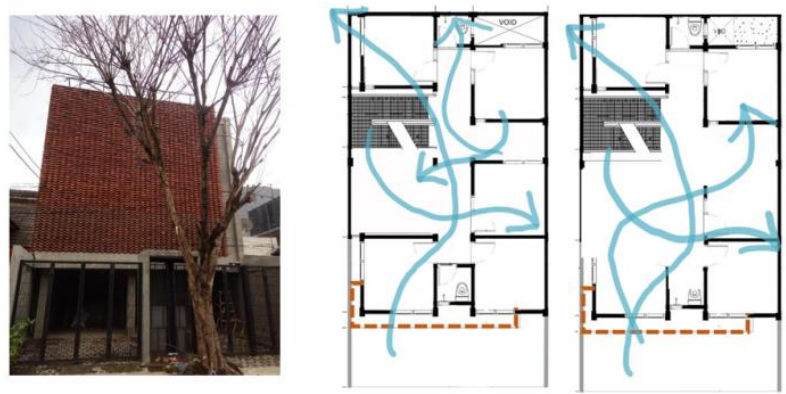

Figure 13 Keputih Boarding House Volume 6 (Object 6)

\subsubsection{Temperature Reduction}

The measurement result shows that the highest air temperature reduction is in Object 2 and 3. In both objects, ventilation blocks are used as wall partition and building façade material and, at the same time, also acts as ventilation. The ventilation blocks wall in Object 3 can reduce air temperature until $6,2^{\circ} \mathrm{C}$, while in Object 2 is of $5,5^{\circ} \mathrm{C}$.

The temperature reduction of $5.5^{\circ} \mathrm{C}$ in Object 2 occurs in the bedroom on the ground floor. This building has large void and openings, which significantly improve air circulation inside the building. The building has a 1:3 ratio between the void area on the ventilation blocks and the total surface area of the façade.

The temperature reduction of $6.2^{\circ} \mathrm{C}$ occurs in Object 3 . The temperature reduction is quite high, although the ratio between the void area on the ventilation blocks and the total surface area on the façade is only 1:32. Therefore, other factors are also contributing to reducing air 
temperatures, such as the shading of the façade by the roof and vegetation.

For Object 4 and 5, there is a relatively low reduction in air temperature, which is $1.4^{\circ} \mathrm{C}$. The absence of voids is one of the factors causing the decrease in air temperature to be low.

In the 6th object, there is a second wall behind the ventilation blocks façade. Thus, the ventilation is not as good as the other four boarding houses, resulting in a decrease in air temperature of only $2.8^{\circ} \mathrm{C}$.

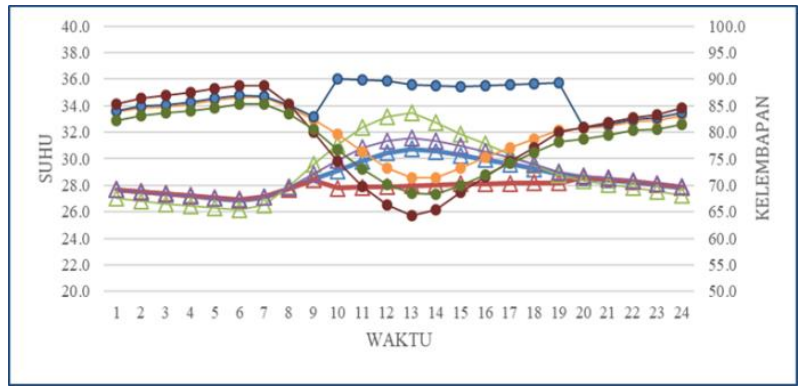

Figure 14 Air temperature in Object 2

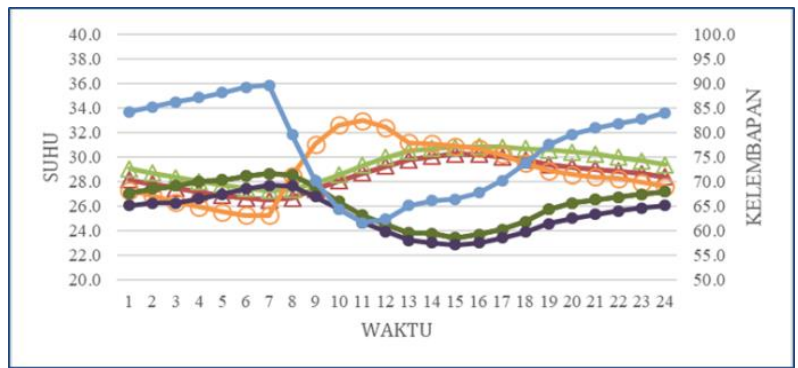

Figure 15 Air temperature in Object 3

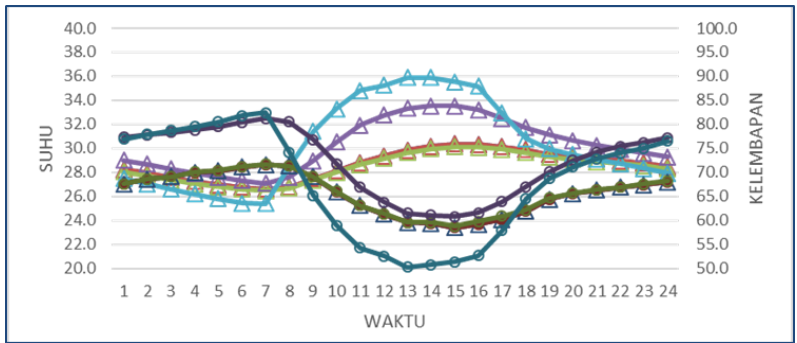

Figure 16 Air temperature in Object 4

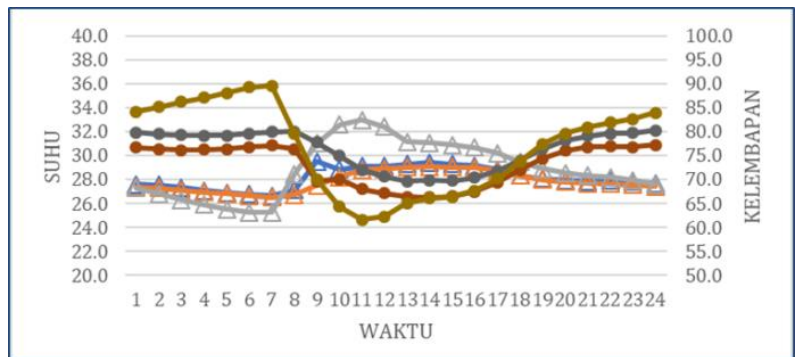

Figure 17 Air temperature in Object 5

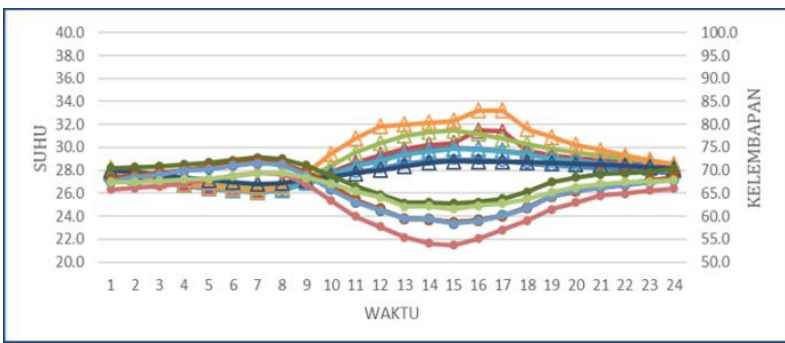

Figure 18 Air temperature in Object 6

\section{CONCLUSION}

The measurement results show that clay bricks can reduce the air temperature up to $3.88^{\circ} \mathrm{C}$, lime bricks up to $1.7^{\circ} \mathrm{C}$, and ventilated blocks up to $6.2^{\circ} \mathrm{C}$. The comparison shows that the highest temperature reduction occurs in the building made of ventilation blocks walls, followed by clay bricks walls and lime bricks walls. However, further research needs to be done about other factors that can affect the amount of air temperature reduction in each material.

\section{REFERENCES}

[1] Purnama, D. E, Nugroho, A. M., Soebandono, Y. B. Identifikasi Pengaruh Material Bangunan Terhadap Kenyamanan Termal (Studi kasus bangunan dengan material bambu dan bata merah di Mojokerto). Jurnal Mahasiswa Teknik Arsitektur Vol. 4, No. 1 (2016).

[2] Nailufar, L \& Yulita, E. N. Kinerja Material Bata Kapur terhadap Kenyamanan Termal Rumah Tinggal di Kabupaten Tuban. Jurnal Mahasiswa Teknik Arsitektur Vol. 5, No. 4 (2017).

[3] Khaira, N \& Nugroho, A. M. Pengaruh Desain Roster terhadap Kenyamanan Termal Bangunan (Studi Kasus Kos Keputih Andy Rahman). Jurnal Mahasiswa Teknik Arsitektur Vol. 7, No. 2 (2019).

[4] Nugroho, M. A. Ahmad, H. M. \& Ossen, R. D. “A Preliminary Study of Thermal Comfort in Malaysia's Single Storey Terraced House". Journal of Asian Architecture and Building Engineering. IV (1) (2007) 175-182.

[5] SNI 03-6572-2001 tentang Tata Cara Perancangan Sistem Ventilasi dan Pengondisian Udara pada Bangunan Gedung. Jakarta: BSN, 2001. 